\title{
PEMBERDAYAAN KOMUNITAS KOPA DI KAMPUNG AUR DALAM PEMANFAATAN LIMBAH KONSTRUKSI MENJADI GREEN WALL
}

\author{
Irma Novrianty Nasution $^{1 *}$, Syahreza Alvan ${ }^{1}$, Novalinda ${ }^{1}$ \\ Jurusan Pendidikan Teknik Bangunan, Fakultas Teknik, Universitas Negeri Medan, \\ Jl. Willem Iskandar pasar V-Kotak Pos No. 1589 - Medan 20221 \\ *Penulis Korespodensi : irmanasution@unimed.ac.id
}

\begin{abstract}
Abstrak
Kondisi Kampung Aur yang memprihatinkan dari segi sosial, ekonomi, lingkungan, psikologi, mental, dan pendidikan masyarakat yang jauh dari kemapanan hidup banyak menimbulkan berbagai permasalahan. Masalah utama yang terlihat jelas yaitu lingkungan permukiman yang padat, kumuh, kurang sehat, tidak asri dan nyaman. Keterbatasan lahan dan ketersediaan ruang hijau yang minim semakin memberi kesan lingkungan yang kumuh. Untuk itu, perlu dikembangkan langkah-langkah nyata untuk menciptakan lingkungan permukiman yang lebih asri, hijau, dan nyaman tersebut. Upaya pengembangan berkelanjutan yang didengung-dengungkan, baik dalam lingkup lingkungan maupun arsitektur, menuntut setiap individu untuk waspada atas bahaya yang mengancam kelangsungan hidup manusia di masa mendatang akibat mengabaikan permasalahan lingkungan. Salah satu bahaya yang mengancam adalah praktek konstruksi dengan limbah yang dihasilkannya. Dalam upaya mendukung program berkelanjutan, maka kegiatan ini direncanakan untuk memanfaatkan limbah konstruksi seperti batu-bata, pipa paralon, bambu dan atau kayu untuk dimanfaatkan sebagai green wall yang dapat diaplikasikan sebagai pekarangan vertikal menggantikan pekarangan yang tidak tersedia karena keterbatasan lahan yang ada. Melalui pemberdayaan komunitas yang ada di Kampung Aur dalam memanfaatkan limbah konstruksi ini diharapkan dapat meningkatkan kualitas lingkungan permukiman yang lebih baik lagi dari kondisi awalnya. Dengan begitu, anggota masyarakat memiliki wawasan baru, inisiatif dan kreativitas untuk mengembangkan konsep serupa secara mandiri di masa-masa mendatang.
\end{abstract}

Kata kunci: Kampung Aur, komunitas, limbah konstruksi, green wall

\begin{abstract}
Many problamatic conditions of Kampung Aur concern in terms of social, economic, environmental, psychological, mental, and educational communities far from the establishment of life. The clearly main problem show the neighborhoods are crowded, unsanitary, not beautiful and comfortable enough. The limitation of land use and the less availability of green space are gives the impression of a polluted environment. Therefore, it is necessary to develop real ways to create a more beautiful living environment, green, and comfortable. The sustainable development efforts that was touted, both in environmental and architectural, require individuals to be aware of the dangers that threaten human survival in the future as a result of ignoring environmental problems. One of the dangers is practice of construction with the waste it generates. The effort to support the sustainable program by doing activities are planned to take advantage of construction waste such as bricks, the pipe, bamboo or wood to be used as a green wall which can be applied as vertical garden. It can be replacing its grounds are not available because of limitation of land use which exists. Through the empowerment of communities in Kampung Aur in the use of construction waste is expected to improve the quality of the living environment better than the initial conditions. Therefore, the community have a new insight, initiative and creativity to develop similar concepts independently in the future.
\end{abstract}

Keywords: Kampung Aur, community, construction waste, green wall 


\section{PENDAHULUAN}

Sungai Deli merupakan satu dari delapan sungai yang ada di Kota Medan. Saat ini, kondisi Sungai Deli sangat memprihatinkan sebab perilaku masyarakat kota yang tidak tertib membuang sampah dan limbah. Pencemaran Sungai Deli $70 \%$ dicemari oleh limbah domestik dan $30 \%$ dicemari oleh limbah industri (Kompasiana, 2015). Situasi ini mengakibatkan sungai mengalami pendangkalan di beberapa titik, penurunan daya dukung sungai, kualitas air sungai dan kualitas lingkungan permukiman di bantaran sungai.

Pada hakekatnya, permasalahan lingkungan bantaran Sungai Deli tidak terlepas dari permasalahan tata ruang kota dan pertumbuhan penduduk yang semakin pesat. Pembangunan yang marak dilakukan di tengah kota maupun di sekitar sungai mengakibatkan masyarakat dengan penghasilan rendah terdesak ke daerah pinggiran sungai untuk tinggal dan bermukim. Kondisi demikian secara nyata meningkatkan lingkungan permukiman marginal di masa-masa mendatang. Oleh karena itu, perlu dilakukan kegiatankegiatan yang dapat membuka wawasan masyarakat dengan tujuan merubah pola pikirnya ke arah yang lebih positif secara perlahan-lahan.

Dalam membenahi lingkungan permukiman masyarakat di Kampung Aur perlu dilakukan pendekatan penciptaan rasa harga diri dan percaya diri sebagai bagian dari masyarakat kota dan penggalakan motivasi membangun dari dalam melalui wahana partisipasi seperti rembug kampung, arisan atau koperasi. Rumah bagi kaum marginal bukanlah sekedar tempat bernaung melainkan sekaligus tempat usaha, ajang bersosialisasi, dan berbagai kegiatan yang sastra gatra/multi dimensi (Budihardjo, 2006).

Masyarakat Kampung Aur merupakan kelompok masyarakat berpenghasilan rendah dengan kondisi lingkungan yang memprihatinkan. Sumber mata pencaharian sehari-hari masyarakat dengan berdagang kecil-kecilan di pekarangan rumah yang sempit dan padat, bahkan tidak jarang mesjid menjadi tempat menjajakan dagangan. Selain berdagang, masyarakat di Kampung Aur juga memiliki usaha kecil seperti warung nasi, warung bahan-bahan pokok dan sebagian lainnya bekerja sebagai tenaga kerja di luar negeri (TKI ke Malaysia).

Kehidupan sosial di sekitar kampung sangat bersahabat. Masyarakat hidup dengan toleransi, memiliki rasa kebersamaan dan hidup bergotongroyong dengan baik. Dengan keterbatasan finansial, masyarakat Kampung Aur tidak seluruhnya mampu membiayai sekolah anak-anaknya. Anak-anak usia sekolah di lingkungan tersebut masih banyak butuh perhatian terutama masalah pendidikan formal dan kejiwaannya di kemudian hari. Tidak jarang ditemui anak-anak yang putus sekolah. Anak-anak demikian sangat rentan terpengaruh nilai-nilai buruk dari dalam dan luar lingkungan seperti vandalisme, kenakalan remaja, dan narkoba. Kondisi Masyarakat ini sangat memprihatinkan dan butuh dibimbing secara mental, spiritual dan ekonominya agar mampu mengembalikan harga diri dan kepercayaan dirinya sebagai bagian dari masyarakat kota.

Permasalahan utama Kampung Aur yaitu lingkungan kumuh, padat dan tidak ada penghijauan atau ruang terbuka hijau. Pemanfaatan lahan permukiman dan pekarangan rumah belum tertata dan terfasilitasi oleh kesan hijau, asri dan nyaman. Sehingga lingkungan dan rumah-rumah warga terkesan kumuh dan padat, serta sesak dengan dinding-dinding batu bangunan. Pemanfaatan limbah konstruksi menjadi dinding hijau (green wall) diharapkan mampu menciptakan lingkungan yang asri, nyaman, hijau, dan memberikan suasana baru yang menyegarkan bagi warga dan lingkungan. Sementara itu, limbah konstruksi yang digunakan sebagai wadah untuk membuat green wall tidak terbuang sia-sia, dapat dimanfaatkan kembali menjadi barang yang berguna bagi kehidupan manusia. Dan anggota masyarakat di lingkungan permukiman Kampung Aur diharapkan terbangun inisiatif dan kreativitasnya untuk memanfaatkan limbah lainnya bagi kebutuhan hidup sehari-hari.

Dengan adanya program Pengabdian Kepada Masyarakat yang dilakukan secara partisipatif diharapkan mampu membuka wawasan dan perlahanlahan menumbuhkan kepedulian masyarakat terhadap perbaikan kualitas lingkungan permukiman. Sehingga masyarakat di lingkungan Kampung Aur dapat meningkat rasa percaya diri dan rasa kebersamaan dalam menjaga lingkungan permukiman yang sehat dan nyaman.

\section{BAHAN DAN METODE}

Permasalahan utama yang dialami oleh masyarakat Kampung Aur adalah tingkat kepedulian yang rendah dalam hal memelihara dan menjaga kualitas lingkungan permukiman yang bersih, sehat dan nyaman. Kemampuan masyarakat untuk meningkatkan kualitas permukiman terkendala oleh pemahaman dan tingkat kepedulian yang kurang, dan pemenuhan kebutuhan hidup sehari-hari yang sulit. Melalui program kinerja, anggota masyarakat dipupuk kepeduliannya untuk menjaga lingkungan permukiman yang hijau, asri dan nyaman.

Metode ataupun pendekatan yang dilakukan sedapat mungkin disesuaikan dengan kebutuhan dan kemampuan yang dimiliki masyarakat, serta memiliki nilai berkelanjutan di kemudian hari. Program kinerja dalam meningkatkan kualitas lingkungan permukiman dilakukan secara partisipatif kelompok masyarakat, dalam hal ini komunitas, yaitu dengan memberdayakan potensi masyarakat yang ada.

Solusi yang ditawarkan dalam meningkatkan kualitas lingkungan permukiman yaitu melalui pembuatan taman tegak/dinding hijau, selanjutnya disebut green wall. Pembuatan diupayakan menggunakan bahan dan alat dari limbah konstruksi antara lain: bambu, pipa paralon, kawat kasa, kayu bekas, dan botol plastik. Program kinerja ini dilakukan dengan metode mengumpulkan dan mendata anggota 
komunitas yang berpotensi untuk diberdayakan dalam pembuatan green wall. Green wall yang dibuat kemudian dipasang di rumah-rumah warga yang dipilih berdasarkan lokasi dan bentuk dinding/pekarangan. Kemudian wadah green wall ditanami oleh tanaman hias dan sayuran yang memiliki karakter tanaman ringan dan merambat.

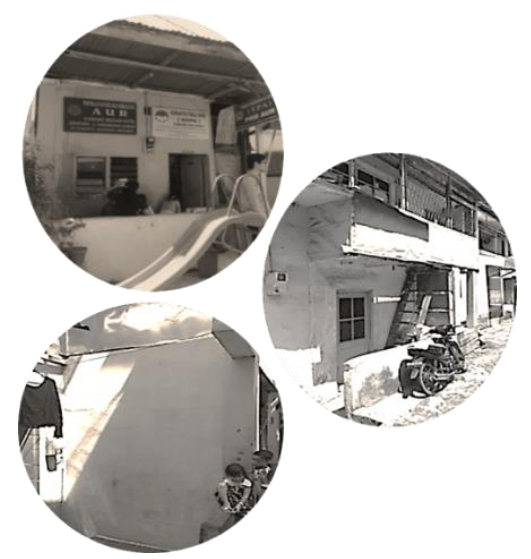

Gambar 1. Lokasi rumah warga yang terpilih untuk dipasang green wall

\section{HASIL DAN PEMBAHASAN}

Program Pengabdian Kepada Masyarakat ini berlokasi di lingkungan IV Kampung Aur. Kondisi lingkungan Kampung Aur yang padat, minim jarak, dan kurang penghijauan menjadi alasan utama kegiatan ini dilaksanakan. Selain itu, pengetahuan dan wawasan kelompok komunitas yang terbatas dalam memanfaatkan limbah dan konsep green wall.

Green wall merupakan konsep taman yang dipilih dan diterapkan pada lahan-lahan terbatas. Green wall yang ditumbuhi tanaman memiliki tujuan antara lain untuk memperindah lingkungan dan untuk memproduksi kadar oksigen yang tinggi terutama pada lahan sempit dan padat.

\section{Model yang diterapkan}

Model green wall yang dipilih adalah taman tegak yang dibangun dari pemanfaatan sisa atau limbah pekerjaan konstruksi. Limbah yang digunakan adalah bambu, pipa paralon, kawat kasa, kayu bekas, dan botol plastik. Rancangan yang dibuat dan diaplikasikan ke lokasi terpilih disesuaikan dengan karakter lokasinya. Adapun lokasi terpilih antara lain kantor komunitas Kopa dan rumah warga (2 lokasi). Lokasi kantor komunitas Kopa dipilih karena lokasi sering dikunjungi oleh tamu dari luar lingkungan Kampung Aur, sehingga green wall dapat menjadi contoh bagi komunitas lain. Rumah warga 1 dipilih karena dinding sisi samping rumah awalnya kurang menarik dengan warna cat dinding yang mencolok. Sekitar lokasi sering digunakan warga sebagai tempat berinteraksi antar warga lainnya, sehingga sangat tepat jika dinding yang kosong tersebut dimanfaatkan sebagai penghijauan dan menjadi spot yang menarik di lingkungan permukiman. Dan rumah warga 2 dipilih karena posisi rumah menghadap ke sisi timur, dimana pada pagi hingga siang hari intensitas matahari cukup tinggi dan perlu ada filtrasi atau dinding pembatas untuk menghalangi sinar matahari tersebut.

Setelah konstruksi taman atau wadah terbangun, selanjutnya adalah mengisi wadah dengan media tanam dan tanaman. Jenis media tanam adalah tanah kompos dan jenis tanaman berupa tanaman, hias, tanaman merambat, dan tanaman sayur yang sifatnya ringan dengan perawatan yang sederhana. Selanjutnya, green wall diinisiasi menjadi milik bersama warga kampung Aur dengan pemeliharaan yang dilakukan secara bersama-sama.
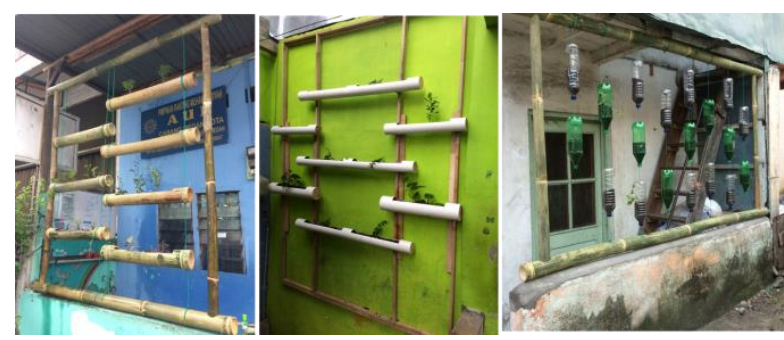

Gambar 2. Model green wall yang diterapkan sesuai karakter lokasi

\section{Proses dan hasil pelaksanaan}

Sesuai dengan rencana yang disepakati, kegiatan dilakukan dengan 5 kali pertemuan pelatihan pembuatan produk green wall dan 2 kali pertemuan sosialisasi terkait tanaman vertikultur dan pemanfaatan limbah konstruksi. Proses awal yang dilakukan pada tahap persiapan adalah penandatanganan Surat Perjanjian Pelaksanaan Kegiatan (SP2K) antara Tim Pelaksana dengan pihak LPM Unimed dan melakukan koordinasi dengan Komunitas Kopa dalam penyediaan lokasi sosialisasi dan kinerja, serta berbagai hal yang berkaitan dengan prosedur administrasi.

Kegiatan dalam program ini dibagi dalam tiga kegiatan antara lain; kegiatan awal, sosialisasi, dan kinerja. Dasar pemikiran pembagian adalah untuk memperoleh tingkat pemahaman warga kampung Aur dari pemahaman dasar ke pemahaman lanjutan. Sehingga warga dan pelaksana memiliki kesamaan persepsi yang sama terhadap tujuan kegiatan dan hasil yang ingin dicapai dari program.

\section{Kegiatan awal;}

Kegiatan ini diawali dengan pendekatan ke komunitas Kopa dan berdialog untuk memperoleh izin dan bentuk kegiatan yang akan dikembangkan.

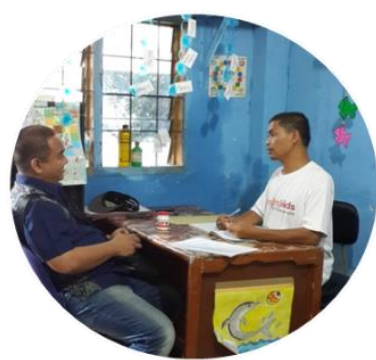

Gambar 3. Dialog dengan komunitas Kopa 


\section{Kegiatan sosialisasi;}

Kegiatan sosialisasi berupa sosialisasi yang berkaitan dengan konsep green wall dan cara bercocok tanam secara hidroponik dan vertikultur. Sosialisasi dilakukan oleh narasumber terpilih yang disesuaikan dengan topik bahasannya dan kegiatan dilakukan dalam dua tahap. Tahap pertama, yaitu penjelasan terkait tujuan dan manfaat program, serta penjelasan tentang konsep green wall dan pemanfaatan limbah konstruksi yang disampaikan oleh narasumber dengan latar belakang keilmuan arsitektur. Kegiatan ini direspon secara positif oleh peserta yang ditandai oleh antusiasme dalam mengajukan berbagai pertanyaan terkait topik bahasan yang disampaikan narasumber. $\mathrm{Di}$ akhir pertemuan para peserta diberi tugas untuk menerapkan cara bercocok tanam sederhana dengan memanfaatkan limbah sayuran dan limbah botol plastik, kemudian dievaluasi pada pertemuan berikutnya.
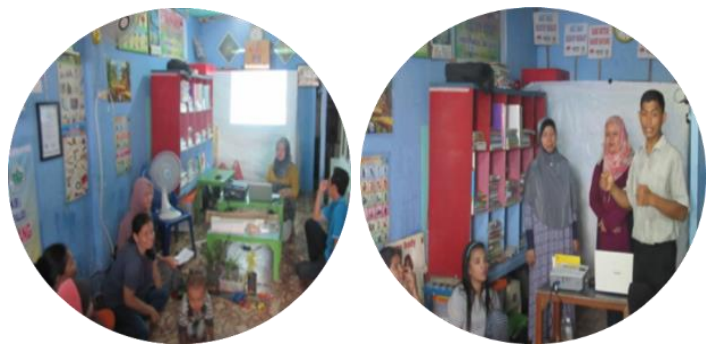

Gambar 4. Kegiatan sosialisasi I dan II

Tahap kedua, yaitu penjelasan terkait cara bercocok tanam dengan hidroponik dan vertikultur, serta pemanfaatan limbah sampah sayuran dan buah menjadi pupuk cair. Penjelasan disampaikan oleh narasumber dengan latar belakang keilmuan Pertanian. Di akhir pertemuan, narasumber menyajikan metode pembuatan pupuk cair dan memberi tugas kepada warga untuk membuatnya secara mandiri. Tugas yang diberikan oleh narasumber direspon secara positif dan warga langsung berinisiatif membentuk kelompok kerja untuk mengaplikasikan pengetahuan yang diterima dalam membuat kompos dan pupuk cair, serta membuat taman sederhana dengan media tanaman sayur sebagai antisipasi gejolak harga pangan yang semakin meningkat.

\section{Kegiatan kinerja}

Setelah komunitas Kopa dan masyarakat Kampung Aur menerima pembekalan melalui sosialisasi, kegiatan lanjutan adalah melatih komunitas Kopa. Proses kinerja yang dilakukan terdiri dari persiapan, pelaksanaan dan pekerjaan selesai. Pada tahap persiapan, terlebih dahulu mengukur lokasi yang akan dipasang green wall dan selanjutnya membuat gambar kerja sebagai modul pelatihan bagi komunitas Kopa.

Langkah selanjutnya adalah mempersiapkan alat dan bahan untuk membuat green wall. Alat dan bahan terdiri dari :
- Alat-alat pertukangan kayu, seperti tang, martil, gergaji, mesin bor, pahat, solder.

- Bahan-bahan untuk membuat rangka taman, antara lain; paku, baut, bambu, kayu 1/2", kawat lembaran, botol bekas, pipa paralon 3", tali pengikat, plat besi siku.

- Bahan-bahan untuk media tanam, jenis tanaman hias dan sayur, antara lain; tanah, kompos, bibit cabai dan tomat, sirih gading, sirih merah, kangkung air, bawang merah dan bawang putih, daun jeruk, samiroto, dolar-dolar, taiwan beauty, melati mini, kalifah.

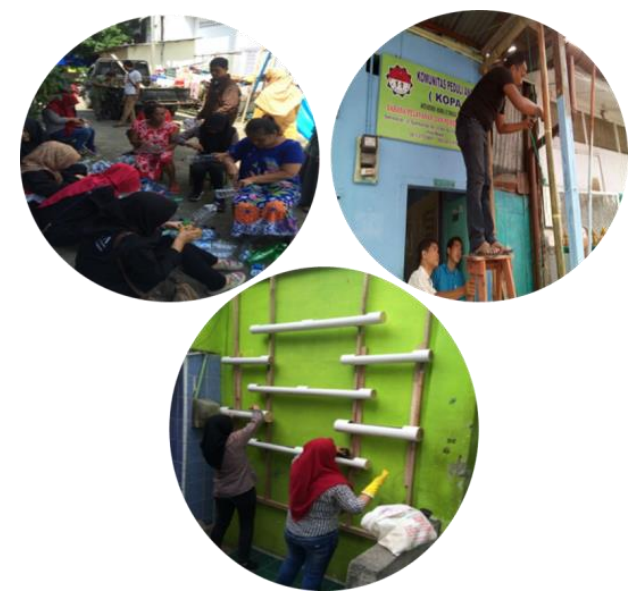

Gambar 5. Kegiatan kinerja

Setelah alat dan bahan dipersiapkan maka dibuat rangka konstruksi dari bambu dan kayu yang akan diterapkan di rumah warga. Bambu, pipa paralon, dan botol plastik yang digunakan sebagai wadah tanam dipotong sesuai ukuran dan desain yang telah ditentukan dalam gambar kerja. Setelah bahan dipotong kemudian wadah dirangkai menjadi bentuk yang diinginkan sesuai hasil rancangan. Dan selanjutnya wadah yang telah selesai dipasang diberi media tanam berupa kompos dan tanaman yang sesuai.

\section{Luaran}

- Menghasilkan produk green wall yang terpasang di rumah warga

- Anggota kelompok komunitas Kopa mampu memberdayakan warga sekitar dalam mengembangkan produk green wall

- Anggota kelompok komunitas Kopa mampu memanfaatkan limbah-limbah yang ada untuk menopang kebutuhan harian

- Anggota komunitas Kopa mampu melakukan penghijauan secara partisipatif dengan warga

\section{Dampak kegiatan}

Dampak kegiatan ini terlihat jelas terutama bagi anggota komunitas Kopa dan warga/masyarakat Kampung Aur. Bagi anggota komunitas, dampak kegiatan adalah memperoleh wawasan baru dan pengetahuan awal untuk dapat disebarluaskan ke masyarakat lain di sekitar lingkungannya. Komunitas dapat berperan sebagai koordinator dalam pembuatan green wall bagi warga lain yang belum memperoleh 
pengetahuan dan keterampilan tersebut. Kegiatan program dapat menjadi contoh kegiatan di lingkungan permukiman sekitar Kampung Aur dan komunitas Kopa dapat menjadi "agen lingkungan" yang dapat berpartisipasi dengan warga dalam memperbaiki kualitas lingkungan permukiman melalui green wall.

Dampak nyata bagi warga yaitu muncul minat bercocok tanam dengan cara vertikultur dan pemanfaatan limbah sayur/buah, serta memanfaatkan limbah sayur/buah sebagai pupuk cair untuk media tanam dan vitamin tanaman. Peningkatan ini ditandai oleh "tugas menanam" yang disampaikan narasumber pada saat kegiatan sosialisasi diapresiasi dengan baik oleh beberapa warga dan warga menyatakan keberhasilannya dalam bercocok tanam dengan limbah sayur/buah tersebut. Warga juga mulai berpikir dan memiliki niat untuk menata pekarangan/rumah dengan memanfaatkan limbah-limbah yang ada seperti botol plastik/kaca, kantong plastik, karung beras, kaleng, dan lain-lain. Namun, perlu dilakukan pendampingan yang terus-menerus di Kampung Aur sehingga warga tergugah hatinya dan berkeinginan kuat dalam waktu singkat melakukan penataan atau peningkatan kualitas hidupnya melalui kegiatan penghijauan. Disamping itu, perlu ada alternatif kegiatan program yang berkelanjutan dari program yang telah dilakukan saat ini.

Tingkat keberhasilan kegiatan Program Pengabdian Kepada Masyarakat ini dapat dilihat dari indikator keberhasilan kegiatan pada Tabel.1 berikut.

Tabel 1. Indikator Keberhasilan Kegiatan Pemberdayaan Komunitas Kopa di Kampung Aur dalam Pemanfaatan Limbah Konstruksi menjadi green wall

\begin{tabular}{|c|c|c|c|}
\hline No & Indikator & Awal & Akhir \\
\hline 1 & $\begin{array}{l}\text { Ruang terbuka } \\
\text { (pekarangan/ter } \\
\text { as/halaman) }\end{array}$ & $\begin{array}{l}\text { Belum } \\
\text { dimanfaatkan }\end{array}$ & $\begin{array}{l}\text { Sudah } \\
\text { dimanfaatkan }\end{array}$ \\
\hline 2 & $\begin{array}{l}\text { Meningkatkan } \\
\text { pengetahuan } \\
\text { dan } \\
\text { keterampilan } \\
\text { anggota } \\
\text { komunitas Kopa } \\
\text { dalam } \\
\text { memanfaatkan } \\
\text { limbah } \\
\text { konstruksi }\end{array}$ & $\begin{array}{l}\text { Belum memiliki } \\
\text { pengetahuan dan } \\
\text { keterampilan }\end{array}$ & $\begin{array}{l}\text { Telah memiliki } \\
\text { pengetahuan } \\
\text { dan } \\
\text { keterampilan } \\
\text { membuat green } \\
\text { wall (kategori } \\
\text { baik) }\end{array}$ \\
\hline 3 & $\begin{array}{l}\text { Minat bercocok } \\
\text { tanam dan } \\
\text { membuat green } \\
\text { wall oleh warga }\end{array}$ & $\begin{array}{l}\text { Ada minat tetapi } \\
\text { ragu dengan } \\
\text { kondisi lahan dan } \\
\text { belum } \\
\text { mengetahuai ada } \\
\text { sistem green wall }\end{array}$ & $\begin{array}{l}\text { Memiliki } \\
\text { keyakinan } \\
\text { untuk bercocok } \\
\text { tanam di lahan } \\
\text { terbatas } \\
\text { (membuat } \\
\text { kelompok kecil } \\
\text { untuk bercocok } \\
\text { tanam dengan } \\
\text { wadah dari } \\
\text { limbah yang } \\
\text { ada) }\end{array}$ \\
\hline
\end{tabular}

4 Jumlah keterlibatan warga

Tidak ada yang
terlibat dalam
kegiatan
perbaikan
lingkungan
melalui
penghijauan

Warga terlibat dalam kegiatan program dan memiliki antusiasme yang cukup tinggi

\section{Evaluasi kegiatan selesai}

Evaluasi kegiatan dilakukan untuk menilai hasil kerja yang telah dilakukan pada program ini. Evaluasi dilakukan terutama pada produk green wall yang terpasang dan pertumbuhan tanaman, serta evaluasi terhadap program komunitas Kopa terkait pemanfaatan limbah.

Evaluasi dilakukan setelah 2-3 minggu setelah kegiatan kinerja berlangsung. Pada saat evaluasi ditemukan produk green wall yang rusak antara lain tali penggantung wadah yang putus, posisi wadah bambu yang miring akibat simpul tali kurang baik, dan jenis tanaman hias dan sayur yang rusak. Selanjutnya, akan dipilih jenis tali penggantung yang lebih baik dan sesuai dengan karakter wadah. Pemilihan media tanam sebaiknya yang ringan (bukan tanah) sehingga wadah tidak miring akibat beban media tanam yang berat. Dan pemilihan jenis tanaman yang sesuai dengan kondisi lokasi (lokasi yang banyak atau sedikit memperoleh sinar matahari), sehingga tanaman dapat tumbuh lebih lama dan subur.

Pada saat evaluasi berlangsung, komunitas Kopa belum melakukan kegiatan serupa. Namun, anggota kelompok komunitas Kopa telah merencanakan kegiatan-kegiatan lainnya seperti pembuatan pupuk cair dari limbah sayur, buah, dan dedaunan. Untuk itu perlu ada pendampingan yang berkesinambungan agar kelompok komunitas dapat mengembangkan program ini lebih lanjut.

Tabel 2. Hasil evaluasi kegiatan terhadap produk green wall

\begin{tabular}{|l|l|}
\hline Program Selesai & Tahap Evaluasi \\
\hline Tanaman baru ditanam & Tanaman tumbuh subur \\
\hline Tanaman baru ditanam & Tanaman tumbuh subur \\
\hline
\end{tabular}




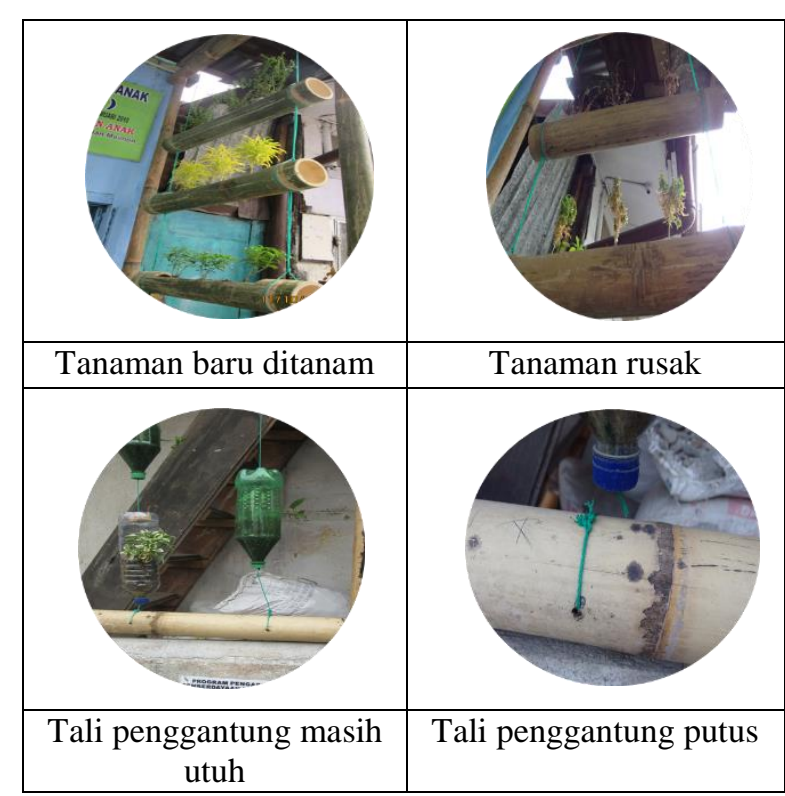

\section{TINDAK LANJUT}

\section{Rencana aktifitas pada tahun berikutnya}

Setelah menguasai pengetahuan dan keterampilan mengolah limbah konstruksi menjadi green wall diharapkan kegiatan ini dapat berlanjut ke rumah-rumah warga lainnya dan lingkungan sekitar permukiman Kampung Aur. Kekurangan dari kegiatan ini masih banyak yang harus dibenahi baik dari segi pemilihan bahan limbah, pemilihan jenis tanaman yang akan ditanam, serta desain green wall yang kontekstual dengan lokasi maupun lingkungan permukiman di Kampung Aur. Selain itu, upaya meningkatkan kreativitas warga dan minat warga untuk menerapkan pengetahuan yang diperoleh melalui kegiatan sosialisasi dan kinerja perlu ditingkatkan dengan pendampingan yang berkelanjutan.

Kegiatan-kegiatan yang melibatkan warga sangat penting dilakukan terus-menerus terutama yang membangkitkan daya kreatif dan wawasan warga yang luas terkait lingkungan. Tantangan besar untuk menciptakan kualitas lingkungan yang baik serta mendukung program "pengembangan berkelanjutan" adalah dengan menumbuhkan kesadaran masyarakat Kampung Aur melalui pendekatan yang persuasif dengan berbagai kegiatan yang menarik minat masyarakat dan dilakukan secara partisipatif. Misalnya, gerakan penghijauan dengan tujuan menciptakan lingkungan yang asri dan dapat mencukupi kebutuhan rumah tangga melalui bercocok tanam sayuran yang pada akhirnya dapat menjadi sumber pendapatan keluarga.

Kaum bapak dan remaja adalah kelompok masyarakat yang perlu mendapat perhatian khusus terkait berbagai kegiatan perbaikan di lingkungan Kampung Aur dan peningkatan kualitas lingkungan adalah hal paling utama yang menjadi perhatian selanjutnya. Maka kegiatan yang akan dilakukan pada tahun berikutnya adalah melalui pemberdayaan kaum bapak dan remaja dalam perbaikan lingkungan melalui pemanfaatan nilai-nilai lokal, kontekstual, dan pengembangan wawasan kreatif yang bernilai ekonomis sehingga mereka mampu bangkit dan percaya diri sebagai bagian dari Kampung Aur yang selama ini terpinggirkan.

\section{Skema keberlanjutan kegiatan}

Harapan di masa mendatang adalah kolaborasi antara akademisi (PT), birokrasi dalam rangka membina masyarakat kaum marginal yaitu masyarakat Kampung Aur dan sejenis agar mereka memiliki kesadaran dan pemahaman yang luas akan pentingnya menjaga lingkungan permukiman yang sehat dan nyaman. Akademisi dengan pengetahuannya memberikan ilmu, berbagi dan berpartisipasi untuk menunjukkan kepedulian terhadap masyarakat agar mereka memiliki kepercayaan diri yang tinggi dan optimis menyongsong kehidupan yang semakin berkembang dan pesat.

Kesadaran terhadap lingkungan dilakukan dengan berbagai upaya atau kegiatan bersama dengan melibatkan masyarakat, pemangku kebijakan, akademisi, LSM, dan semua pihak yang peduli dalam pengembangan kawasan permukiman dengan segala permasalahannya.

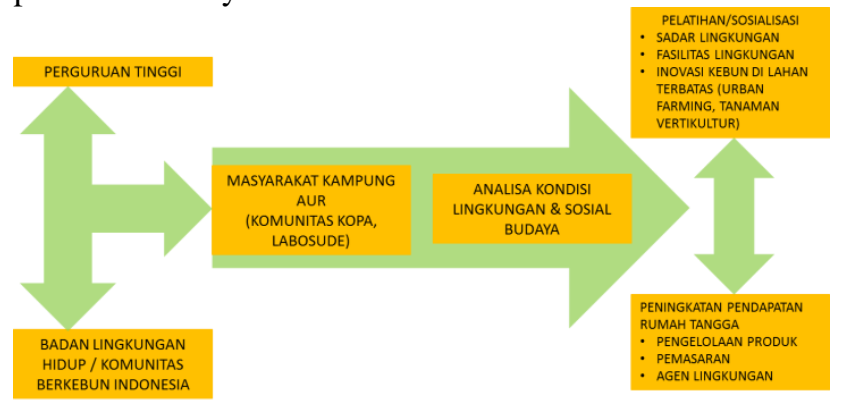

Gambar 6. Skema keberlanjutan kegiatan

\section{KESIMPULAN}

Berdasarkan hasil kegiatan Pemberdayaan Komunitas Kopa di Kampung Aur Melalui Pemanfaatan Limbah Konstruksi Menjadi Green Wall yang telah dilaksanakan, maka dapat disimpulkan sebagai berikut :

- Anggota komunitas Kopa telah memperoleh pengetahuan dan keterampilan membuat green wall melalui pemanfaatan limbah konstruksi seperti pemanfaatan bambu, pipa paralon, dan botol bekas, menjadi green wall dengan tipe gantung dan melekat di dinding. Produk yang dihasilkan adalah produk yang sederhana dan mudah untuk diterapkan ke warga Kampung Aur di lokasi-lokasi lainnya.

- Komunitas Kopa bersama dengan warga Kampung Aur telah membentuk kelompok-kelompok kecil untuk mengembangkan green wall dan menjalankan gerakan penghijauan di lingkungan permukiman melalui pembuatan pupuk cair melalui pemanfaatan limbah sayur, buah, dan sampah tanaman. 


\section{UCAPAN TERIMA KASIH}

Terima kasih disampaikan kepada LPM UNIMED yang telah mendanai keberlangsungan jurnal ini.

\section{DAFTAR PUSTAKA}

Budiharjo, Eko. (2006). Percikan Masalah Arsitektur, Perumahan, Perkotaan (p.68). Yogyakarta: Gadjah Mada University Press.

http://www.kompasiana.com/julyono/sungai-delicerminan-kebanggaan-kota medan_55be08d2e9afbd5c09bec082 